\title{
Profil Rasul Paulus Dalam Surat 1 Korintus Dan Relevansinya Bagi Hamba-Hamba Tuhan Di Gereja Pantekosta di Indonesia Rungkut Surabaya
}

\author{
Julianus Zaluchu
}

\author{
Evangelical Theological Seminary of Indonesia - Surabaya \\ E-mail: julianuszaluchu@sttii-surabaya.ac.id
}

Abstract. The profile of God's servants is a very important teaching that God has entrusted to His church on this earth. God's servants often face enormous challenges in delivering the teachings of God's Word. Such as offers to compromise, participate in committing crimes, unhealthy ambitions to gain a position, engage in the business world and materialism.

In the use of wisdom it is not uncommon for God's servants to make their own decisions without involving God. In terms of ethics, God's servants experienced a fall by the temptation of wealth, throne and women. There is even a servant of God directly involved in business and politics so that it deviates far from the teachings of God's Word. Many of God's servants consider it more powerful and pretend to know because they have many congregations, and have spiritual gifts such as speaking in tongues.

To get maximum results, in this study the authors used qualitative research methods, historical research methods and descriptive research methods. Qualitative research methods by distributing questionnaires to congregants and to several servants of God who serve in the GPdI Rungkut church. This study collected data from the results of the distribution of questionnaire sheets to 175 eligible congregations to fill them.

The conclusions of this research are 1) The Apostle Paul is a servant of God who was called by God to carry out His mission, which is to preach the gospel of Jesus Christ to all people; 2) First Corinthians describes the profile of the apostle Paul as a servant of God; 3) The Apostle Paul as a servant of God should be emulated by God's servants in Indonesia in general and in particular God's servants in the GPdI Rungkut Surabaya church; 4) God's servants must have knowledge about the profile taught by the apostle Paul so that they have a humble attitude, that is, an attitude that is not defensive when faced with resistance and a sincere attitude to help others; 5) Servants of God serve willingly and not accentuate their ministry so that praise is given from God not from humans; and 6) Servants of God have integrity and strict adherence to the spiritual laws contained in God's word.

Keywords: Profile, 1 Corinthian, Servant of God, Church

\section{LATAR BELAKANG}

Hamba Tuhan memiliki tempat yang mulia di hadapan Tuhan Yesus, karena hamba Tuhan dipilih dan ditentukan atas inisiatif-Nya, untuk melayani Tuhan melalui pelayanan terhadap umat-Nya. Kesadaran dan keyakinan akan panggilan Tuhan dalam hidup seseorang akan terlihat dari sikap dan perbuatannya yang sesuai dengan Firman Tuhan yaitu menolong orang lain yang berada dalam kesulitankesulitan, masalah-masalah dan tantangan dengan cara mengidentifikasi diri dengan orang-orang yang dilayani tanpa menghilangkan identitas.
Hamba Tuhan mempunyai peranan penting dalam mengasihi, menasehati, membantu dan menolong orang-orang dilingkungan sekitarnya sebagaimana Allah mengasihi umat-Nya (1 Yoh 4:7-19). Ini adalah dasar pelayanan hamba Tuhan untuk memuliakan Allah di dalam Yesus Kristus sebagai Juruselamat manusia. Douglas menjelaskan hamba Tuhan sebagai pelayan artinya seseorang yang bekerja untuk keperluan orang lain dan ia bekerja menjadi milik tuannya.

Seorang hamba Tuhan memiliki kehidupan yang berpusat pada Tuhan dalam 
segala sesuatu yang dilakukannya. Sebagai orang beriman yang meyakini panggilan Tuhan dalam hidupnya senantiasa melakukan persekutuan dengan sesama. Hamba Tuhan membantu orang yang mengalami pergumulan sehingga menemukan pengharapan tentang anugerah Allah dalam Kristus Yesus sebagai Juruselamat pribadinya.

Hamba Tuhan saling berbagi dengan sesama, membangun lingkungan yang berhubungan dengan orang lain untuk menyatakan kasih Allah sehingga memuliakan Allah dalam Yesus Kristus. Inilah yang menjadi jatidiri hamba Tuhan yaitu memiliki kepekaan terhadap pergumulan jemaatnya. Menyatakan ajaran Allah tentang pengampunan kepada sesama dan menunjukkan pemeliharaan Allah bagi manusia yang mau berharap kepada pertolongan Allah. Hamba Tuhan merupakan pelayan bagi sesama yang mengandalkan hikmat Allah untuk memuliakan Yesus Kristus. Dalam perkembangan dunia modern ini ditemukan keberagaman hidup hambahamba Tuhan yang kompleks. Seperti adanya kemorosotan pelayan Tuhan yang condong ke sekuler.

Ada hamba Tuhan yang menuntut honor tertentu, harus naik pesawat, menuntut diperlakukan sebagai tamu VIP dengan rombongan yang harus tinggal di hotel berbintang lima, bahkan ada yang menuntut disediakan perangkat sound system yang paling komplit dan datang dengan tim penyanyi.

Ini ada benarnya seperti yang dikatakan Hobbes yang dikutip oleh Darmaputera bahwa tabiat manusia itu adalah tamak dan serakah terhadap harta. Naluri ketamakan dan keserakahan akan membuat manusia bersikap serigala terhadap sesamanya (Homo Homini Lupus). Dan yang terjadi adalah suatu keadaan perang antara sesama melawan semua (war of All against all). Inilah keserakahan manusia terhadap materi yang hanya memperhatikan kepentingan sendiri, tanpa melihat kepentingan orang lain.

Panggilan Allah diberikan kepada orang percaya untuk menggunakan uang atau harta dalam batas-batas kehidupan rohani yang disiplin, tepat dan mengelola uang demi kebaikan seluruh umat manusia dan untuk kemuliaan Allah. Lebih lanjut Barnett menjelaskan uang sebagai berikut: Money is an essential aspect of life, and all of life is spritual. The sacred secular distinction are artificial. We can bring glory to God with our finances. We can enjoy money with thanksgiving our relationship to God's material provision should be one of contant celebration. Allah dapat memenuhi keperluan pokok manusia yang mengalami kasih sebab Ia tahu apa yang dibutuhkan manusia.

Gejala sekularisasi ada banyak dilihat pada hamba Tuhan masa kini dalam pemakaian barang mewah. Lebih menyedihkan lagi adanya kesaksian dari beberapa hamba Tuhan, ada yang bersaksi bahwa ketika bertobat diusir dari keluarganya dan hanya memiliki selimut yang menempel di badan, tetapi ketika sudah populer mengenderai mobil mewah. Ada yang mengaku dari awalnya sangat miskin sekali bahkan kalau makan dari sisa-sisa makanan orang yang dibuang di tempat sampah, ketika sudah populer membanggakan berkat yang diterimanya berupa sertifikat tanah, rumah mewah dan mobil. Bandingkan hal ini dengan khotbah Yesus tentang upah mengikut Dia (Mat. 19:27-30).

Memang benar bahwa Yesus menjanjikan setiap orang percaya akan memperoleh hidup berkelimpahan tetapi bukan ditafsirkan sebagai kaya materi. Namun ada hamba Tuhan yang mengumpulkan materi untuk keperluan pribadinya tanpa memperhatikan orang lain disekitarnya. Pembangunan kota (urban development) di Indonesia mengalami laju yang pesat sehingga banyak kota-kota besar menjadi kota raya metropolitan yang modern. Secara tidak langsung mempengaruhi hamba-hamba Tuhan materialisme dan konsumerisme. Ini dimungkinkan karena jumlah uang yang beredar di Indonesia lebih banyak di kota besar seperti Jakarta.

Sekularisme banyak mempengaruhi kehidupan beragama, di mana ada banyak orang Kristen cenderung menjadi sekuler dan meninggalkan agama. Saat ini terjadi perkembangan yang menyedihkan di mana ada banyak orang Kristen yang mengembangkan kehidupan kekristenan yang abu-abu, yaitu tidak meninggalkan agama, tetapi hidup di dalam iman Kristen yang sekuler, kompromi, dan subyektif.

Di satu segi dapat dilihat bahwa secara kuantitatif atau jumlah terjadi pertumbuhan gereja yang luar biasa, tetapi di pihak lain tampak adanya kecenderungan 
bahwa secara kualitatif atau mutu iman ada banyak yang merosot karena pengaruh pluralisme dan relativisme sekuler. Dalam kehidupan hamba Tuhan di perkotaan tak jarang adanya penyimpangan hubungan seksual. Masalah hamba Tuhan masa kini ialah adanya godaan wanita yang ingin memuaskan hasrat birahinya. Kenyataannya, tidak sedikit hamba Tuhan jatuh dalam dosa seksual.

Akibat intimnya hubungan hamba Tuhan dengan jemaatnya akan menciptakan kemesraan. Seharusnya jemaat yang membutuhkan penggembalaan dan pembinaan rohani dari hamba Tuhan, namun yang terjadi adalah saling bermesraan atau melakukan persetubuhan. Ada banyak orang Kristen, tak terkecuali pendeta dan teolog, terjerat dalam seks bebas seperti di gereja pemuja seks bebas family of love atau Children of God, akibat pemahaman yang salah tentang hubungan kasih Agape dan Eros.

Pornografi, perzinahan, bahkan kehidupan gay (homoseksual \& lesbian) makin diterima sebagai bagian dari hidup. Perkosaan, kumpul kebo dan segala bentuk hubungan di luar pernikahan makin lama dianggap biasa. Pornografi menjadi hal yang lumrah dinyatakan di gereja. Tindakan tak bermoral berakar dari jiwa yang membrontak terhadap Allah. Karena manusia menolak tunduk kepada Allah dan menyerahkan kehidupan pada kekuasaan si jahat.

Foster menguraikan bahwa aspek seksualitas manusia ialah adanya persetubuhan yang merupakan kebutuhan manusia seutuhnya. Sebab tubuh memerlukan makanan, udara, dan air, serta memuaskan tubuhnya dengan berhubungan seks. Aspek lain dri seksualitas manusia adalah penghargaan terhadap kecantikan dan daya tarik jasmani. Sangatlah mungkin untuk menghargai kecantikan wajah dan tubuh tanpa hawa nafsu seksual. Menikmati kecantikan tidak perlu berlebihan, hanya perlu dikendalikan.

Di Indonesia terlihat hamba Tuhan mengutamakan sanak saudara sendiri dalam jabatan atau kedudukan dalam pelayanan. Ada banyak roda pelayanan hancur karena ditangani oleh kerabat dekat namun tidak memiliki beban pelayanan untuk membimbing jemaat.

Selanjutnya, Foster menjelaskan bahwa kekuasaan dapat menjadi berbahaya apabila disertai dengan kesombongan. Kekuasaan disertai kesombongan dapat memaksakan kepada orang lain menurut anggapan yang benar dari diri sendiri. Sebagai hamba yang melayani harus memiliki kerelaan pelayanan kepada sesama bukan karena ingin mendapatkan jabatan atau kekuasaan. Dapat dikatakan pelayanan rohani diberikan Tuhan kepada jemaatnya untuk menjadi milik orang percaya yang dipakai dan dipelihara untuk kemuliaan nama-Nya.

Bertolak dari persoalan-persoalan di atas mendorong penulis untuk melakukan penelitian dengan tema: "Profil Rasul Paulus Dalam Surat Satu Korintus Dan Relevansinya Bagi Hamba-Hamba Tuhan di Gereja Pantekosta di Indonesia Rungkut Surabaya."

\section{RUMUSAN MASALAH}

Dalam rumusan masalah ini penulis membuat pertanyaan mendasar untuk mengarahkan dan memperdalam penulisan dengan tema: Profil Rasul Paulus dalam Surat Satu Korintus dan relevansinya bagi hambahamba Tuhan di Gereja Pantekosta di Indonesia Rungkut Surabaya, sebagai berikut: 1. Bagaimana profil seorang hamba Tuhan?

2. Bagaimana profil Rasul Paulus sebagai hamba Tuhan dalam surat Satu Korintus?

3. Bagaimana relevansi profil rasul Paulus dalam Surat Satu Korintus bagi hamba-hamba Tuhan di Gereja Pantekosta di Indonesia Rungkut Surabaya?

\section{MAKSUD DAN TUJUAN}

Bertolak dari latar belakang penelitian, masalah yang telah dikemukakan sebelumnya, maka maksud dan tujuan penelitan sebagai berikut:

1. Untuk memahami dan mempelajari profil hamba Tuhan supaya jemaat dapat mengikuti dan meneladani karakteristik hamba Tuhan yang benar.

2. Untuk memahami dan mempelajari profil Rasul Paulus sebagai hamba Tuhan dalam Surat Satu Korintus supaya dapat meningkatkan kualitas rohani hamba-hamba Tuhan di Gereja GPdI Rungkut Surabaya.

3. Untuk mengetahui relevansi profil rasul Paulus dalam Surat Satu Korintus bagi hamba-hamba Tuhan di Gereja Pantekosta di Indonesia Rungkut Surabaya. 


\section{HIPOTESIS PENELITIAN}

Berkaitan dengan penjelasan dalam hal Profil rasul Paulus dalam Surat Satu Korintus Dan Relevansinya Bagi Hamba-Hamba Tuhan di Gereja Pantekosta di Indonesia Rungkut Surabaya, maka penulis mengemukakan hipotesis penelitan sebagai berikut:

1. Apabila profil hamba Tuhan dapat dipahami dan dipelajari, maka jemaat dapat mengikuti dan meneladani karakteristik hamba Tuhan yang benar.

2. Apabila profil Rasul Paulus sebagai hamba Tuhan dalam Surat Satu Korintus dapat dipahami dan dipelajari, maka akan meningkatkan kualitas rohani hamba-hamba Tuhan di Gereja GPdI

3. Apabila relevansi profil rasul Paulus dalam kitab Satu Korintus terhadap hambahamba Tuhan di Gereja Pantekosta di Indonesia telah diketahui, maka setiap hamba Tuhan yang bernaung di Gereja GPdI Rungkut selayaknya dapat menerapkannya dalam pelayanan sehingga kualitas pelayanan di dalam Gereja semakin meningkat.

\section{ASUMSI PENELITIAN}

Supaya tidak terjadi kesalahpahaman, penulis memberikan penekanan untuk beberapa hal yang menjadi pegangan penulis sebagai asumsi dasar bagi penelitian ini.

Adapun asumsi-asumsi tersebut adalah sebagai berikut:

1. Profil hamba Tuhan adalah pelayanan yang dimandatkan oleh Allah sendiri kepada pribadi tertentu yang dipanggil-Nya secara khusus baik dalam jaman Perjanjian Lama, jaman Perjanjian Baru, dan sepanjang sejarah gereja sampai masa kini.

2. Profil hamba Tuhan adalah salah satu pelayanan dari lima pelayanan utama gereja, yaitu Nabi, Rasul, Penginjil, Guru Injil dan Gembala untuk memperlengkapi orang-orang kudus dalam pelayanan dengan tujuan membangun tubuh Kristus. Karena itu Pengajaran tentang profil hamba Tuhan dilaksanakan secara Alkitabiah dan theologis.

3. Kemajuan dan kemunduran sebuah gereja ditentukan oleh sikap, cara, dan komitmen hamba Tuhan yang telah terpanggil secara khusus dalam pelayanan. Dengan demikian, gereja yang bertumbuh ke arah kedewasaan sangat dipengaruhi oleh pribadi hamba Tuhan.

\section{BATASAN PENELITIAN}

Pokok bahasan penelitian ini adalah penelitian profil hamba Tuhan. Oleh sebab itu, semua bentuk dan metode-metode penelitian akan diarahkan dan difokuskan pada penelitian untuk menemukan dasar-dasar alkitabiah dan teologis dalam hal Profil Rasul Paulus dalam Surat Satu Korintus. Supaya bahasan penelitian ini tidak bergeser dari maksud dan tujuan yang telah ditetapkan sebelumnya, maka penulis menetapkan wilayah dan ruang gerak penelitian ini sebagai berikut:

Walaupun umumnya profil hamba Tuhan memiliki landasan prinsip-prinsip dan metode-metode yang sama berdasarkan Alkitab, namun profil ini senantiasa berhadapan dengan latar belakang konteks yang berbeda. Karena itu penelitian terhadap hamba Tuhan ini diarahkan dalam konteks Gereja Pantekosta di Indonesia Rungkut Surabaya.

Mempelajari profil hamba Tuhan di gereja GPdI Rungkut, penulis akan datang mengedarkan lembaran kuesioner kepada setiap jemaat dan mengadakan wawancara kepada beberapa hamba-hamba Tuhan yang memiliki latar belakang budaya, bangsa, suku, dan konteks historisnya yang berbeda.

\section{DELIMITASI PENELITIAN}

Berkenaan dengan luasnya cakupan pembahasan, maka penelitian ini dengan sengaja akan dibatasi. Bertalian dengan variabel pertama, yaitu Profil Rasul Paulus Dalam Surat Satu Korintus.

Sedangkan variabel kedua, Relevansinya Bagi Hamba-Hamba Tuhan Di Gereja Pantekosta di Indonesia Jemaat Rungkut Surabaya.

\section{DEFINISI ISTILAH}

Adapun judul tesis ini ialah "Profil Rasul Paulus Dalam Surat Satu Korintus Dan Relevansinya Bagi Hamba-Hamba Tuhan Di Gereja Pantekosta Di Indonesia Rungkut Surabaya."

Ada lima istilah yang penulis pandang perlu didefinisikan, supaya pembaca 
dapat memahami maksud bagian (konteks) istilah tersebut dikemukakan untuk mengetahui keseluruhan tulisan ini. Paling tidak, dengan memahami kata kunci tulisan ini, pembaca akan memahami bagian demi bagian, dan keseluruhan tulisan ini, bahkan melalui kelima istilah tersebut, pembaca akan mengikuti alur pikir yang menghantar pembaca pada klimaks dan tujuan yang disajikan pada akhir tulisan ini. Keempat istilah itu ialah Profil, Rasul, Hamba, Relevansi, dan Gereja.

\section{PROFIL}

Istilah "Profil" dalam Kamus Besar Bahasa Indonesia diartikan pandangan dari samping tentang wajah orang atau lukisan (gambar) orang dari samping. Sedangkan Hasan Shadily menjelaskan profil sebagai tampang atau raut muka atau riwayat. Webster's menjelaskan profil sebagai a represented or seen ini a side view or a vertical section of a soil from the ground surface to the underlying unweathered material. Profil dapat dimengerti sebagai biografi atau kisah hidup yang tertuang dalam cerita manusia. Dari pengertian tersebut, maka dapat disimpulkan bahwa istilah profil berkaitan dengan wajah, gambar diri, dan citra manusia.

Hoekema menyatakan bahwa manusia sebagai gambar dari rupa Allah yaitu pertama, manusia harus mencerminkan Allah. Cermin memberikan refleksi, maka manusia pun harus merefleksikan Allah. Saat seseorang melihat manusia, orang tersebut harus melihat refleksi Allah di dalam diri manusia tersebut. Atau dengan kata lain, di dalam diri manusia Allah menjadi kelihatan di bumi. Kedua, manusia juga mewakili Allah. Manusia diciptakan sedemikian rupa sehingga ia bisa mewakili Allah.

Jika benar bahwa ketika orang melihat manusia ia melihat sesuatu tentang Allah di dalamnya, maka ini berarti manusia mewakili Allah di bumi. Sebagai gambar dan rupa Allah maka manusia harus memuliakan Allah sebagai pencipta.

\section{RASUL}

Istilah "Rasul" dalam Kamus Besar Bahasa Indonesia, diartikan orang yang menerima wahyu Tuhan untuk disampaikan kepada manusia. Dalam kamus teologi istilah rasul adalah utusan atau orang yang diutus untuk melakukan tugas atau salah seorang dari kelompok Perjanjian Baru yang diutus untuk mengabarkan Injil.

Menurut Douglas rasul adalah utusan sah dari penguasa agama, dipercayai menyampaikan pesan dan uang dan diberi kuasa untuk bertindak atas nama penguasa itu. Rasul menyatakan orang yang diberi wewenang untuk menyampaikan kabar berita. Sedangkan Brown menjelaskan rasul adalah apostle; The apostle call anda commissioning to lifelong service of an apostle is not through men but through Jesus Christ and God the Father (Gal 1:1, Rom 1:5, 1 Cor 1:1). It comes about through meeting with the risen Lord ( 1 Cor 15:7, Gal 1:16). Who himself gives his apostle the message of the gospel. The service of the apostle makes it clear that the local church is not a law unto itself but under law to Christ. Dapat disimpulkan bahwa istilah rasul berkaitan dengan tugas yang diberikan pada seseorang dengan penuh tanggung jawab untuk menyampaikan ajaran Firman Tuhan dan diberi wibawa sorgawi untuk melaksanakan apa yang dikehendaki Allah.

\section{HAMBA}

Istilah "Hamba" dalam Perjanjian Lama memakai istilah Ebed Yahweh sebagai gelar khusus untuk menggambarkan orangorang yang dipakai Tuhan secara istimewa. Dalam Perjanjian Baru kata hamba dalam bahasa Yunani "Doulos" yang secara harafiah artinya keturunan budak yang tidak mempunyai apa-apa. Menurut tradisi Yahudi, istilah hamba menunjuk kepada budak belian yang telah kehilangan hak hidupnya, ia hidup hanya untuk tuannya. Istilah hamba dalam Kamus Besar Bahasa Indonesia dapat diartikan orang yang mengabdi atau orang untuk merendahkan diri.

Menurut DR. Petrus Octavianus istilah hamba dalam perspektif iman Kristen, istilah hamba Tuhan bukan hanya terbatas pada pengertian pendeta atau penginjil, tetapi juga meliputi para pemimpin dan pemuka masyarakat bahkan semua umat Kristen secara individu, secara fungsional disebut sebaga hamba Tuhan, artinya pelaksana sabda Tuhan.

Dalam kamus teologi dijelaskan arti hamba sebagai orang awam yang dipilih untuk melayani dalam ibadah dan penggembalaan. Jadi hamba berkaitan dengan orang yang melaksanakan tugas tanpa memperhatikan hak 
secara pribadi. Hamba melaksanakan tugas yang diberikan dengan tanggung jawab menyelesaikan dan kerelaan tanpa mendapat imbalan atas hasil pekerjaan yang diselesaikan kepada tuannya.

\section{RELEVANSI}

Istilah "Relevansi" menurut Kamus Besar Bahasa Indonesia diartikan sebagai hubungan atau kaitan atau berguna secara langsung. Hal ini memiliki hubungan yang jelas antara penyataan yang satu dengan penyataan lainnya. Sedangkan Hasan Shadily menjelaskan relevansi sebagai faktor-faktor yang bersangkut paut dengan pokok persoalan.

Menurut Webster's menulis relevan adalah having significant and demonstrable bearing on the matter at issue or under discussion. Relevansi diharapkan dapat memberi hubungan yang baik bagi orang yang membawa profil Rasul Paulus sebagai hamba Tuhan dalam kitab I Korintus untuk dapat diteladani. Istilah relevansi dalam hubungannya dengan tulisan ini memiliki pengertian bahwa pengajaran Rasul Paulus tentang profil hamba Tuhan dalam kitab I Korintus mampu diterapkan bagi hambahamba Tuhan di Gereja Pantekosta di Indonesia Jemaat Rungkut, sebagaimana Rasul Paulus tuliskan dalam 1 Korintus 9:19.

\section{GEREJA}

Kata Gereja berasal dari bahasa Yunani ekklesia, yang terdiri dari dua kata: ek yang berarti "keluar" dan kaleo berarti "memanggil". Jadi, kata ekklesia, secara harafiah berarti "mereka yang dipanggil." Ini dipakai dalam injil yang merujuk pada bangsa Israel dan komunitas orang-orang percaya, baik di sorga dan di bumi (Kisah Para Rasul 7: 39; Ibrani 12: 23; Wahyu 1: 11). Kata "Gereja " memiliki dua pengertian dasar, yakni "universal" dan "lokal." Gereja universal adalah mencakup semua yang telah ditebus di sepanjang masa, baik disorga maupun di bumi, sementara Gereja lokal menjadi ekspresi penampakan dari Gereja universal itu sendiri. Gereja menurut Perjanjian Baru adalah bangsa Yahudi dan bukan bangsa Yahudi. Allah telah memanggil Israel sebagai bangsa dari antara bangsa-bangsa, dan mengangkat mereka sebagai gereja-Nya dalam Perjanjian Lama, maka sekarang Allah memanggil setiap orang untuk datang kepada-Nya dan keluar dari setiap bangsa-bangsa, entah bangsa Yahudi atau bukan Yahudi, dan kemudian mengangkat mereka sebagai gereja-Nya dalam Perjanjian Baru. Gereja Perjanjian Baru disebut sebagai tubuh Kristus yang terdiri dari bangsa Yahudi dan bukan Yahudi. (Matius 16: 18; Kisah Para Rasul 2: 47; Kolose 2: 19; Efesus 1: 22, 23; 2: 15, 16; 3: 6; 1Korintus 12: 13).

Jadi, dengan singkat dapat di sebutkan bahwa Gereja terdiri dari mereka yang mentaati panggilan, tanpa memperdulikan bangsa atau budaya. Mereka dipanggil dari dunia untuk mendengarkan Allah. Karena itu, gereja tidak bersifat kebangsaan atau antar bangsa, bukan juga sebagai golongan keagamaan, sekte atau nonsekte. Gereja adalah seorang manusia yang telah dilahirkan dari air dan roh, dan sekumpulan umat yang baru yang telah Allah cipatakan di bumi.

\section{METODE PENELITIAN}

Untuk mendapatkan hasil yang maksimal, maka dalam penelitian ini penulis menggunakan metode penelitian kualitatif, metode penelitian sejarah dan metode penelitian deskriptif. Metode penelitian kualitatif dengan menyebarkan kuesioner kepada jemaat dan kepada beberapa hamba Tuhan yang melayani di gereja GPdI Rungkut. Metode penelitian sejarah berkaitan dengan penyelidikan, pemahaman, penjelasan dan rekonstruksi peristiwa-peristiwa masa lampau berdasarkan literatur yang tersedia. Tujuannya ialah untuk mencapai kesimpulan sehubungan dengan sebab, akibat atau kecenderungan dari peristiwa masa lampau yang membantu menjelaskan peristiwa masa kini dan membantu mengantisipasi kejadian masa yang akan datang.

Penelitian ini mengumpulkan data dari hasil pengedaran lembar kuesioner kepada 175 jemaat yang layak untuk mengisinya. Dalam penelitian sejarah terkait dengan dua sumber yakni sumber primer (pengetahuan dari orang atau tangan pertama, misalnya laporan dari saksi mata, pendiri atau dokumen asli), dan sumber sekunder (informasi dari orang atau tangan kedua). Evaluasi terhadap penelitian sejarah adalah menyangkut : kritik dalam (menilai kemanfaatan data tersebut), dan kritik luar 
(menafsir/menilai keotentikan dari data). Sedangkan metode penelitian deskriptif berkaitan dengan pengumpulan data untuk memberikan gambaran atau penegasan suatu konsep atau gejala, juga menjawab pertanyaanpertanyaan sehubungan dengan status subyek penelitian pada saat penelitian (sikap atau pendapat terhadap individu, organisasi dan sebagainya).

\section{PENETAPAN JENIS METODE}

Dalam penelitian ini penulis memakai metode penelitian deskriptif kuantitatif. Metode penelitian deskriptif kuantitatif adalah metode yang digunakan untuk meneliti dan menyelidiki sekelompok manusia yang berkaitan dengan kondisi atau situasi tertentu untuk mendapatkan data-data yang akurat berdasarkan fakta sejarah dan relevansinya dengan keadaan masa kini. Karena itu, penulis berusaha mendeskripsikan data-data yang di dapat dengan memakai dua pendekatan penelitian yaitu pendekatan kajian literatur dan pendekatan pengumpulan data lapangan.

\section{PENETAPAN POPULASI DAN SAMPEL}

Dalam hal ini penulis mengambil data yang nantinya akan di analisa. Untuk itu penulis dalam penelitian ini menetapkan populasi dari Jemaat Gereja Pantekosta di Indonesia Rungkut Surabaya. Dari populasi ini, penulis akan menetapkan sampel dan cara pengambilannya ditetapkan dengan akurat.

\section{INSTRUMEN PENELITIAN}

Untuk mendapatkan hasil penelitian yang akurat maka penulis berusaha untuk mendapatkan data yang reliabilitas dan validitas, dengan memakai instrumen penelitian sebagai berikut: a) Kuesioner, menyebarkan daftar pertanyaan kepada seluruh jemaat yang ada di dalam Gereja GPdI Rungkut; b) Wawancara, akan mengadakan wawancara kepada beberapa orang jemaat, pengerja gereja, dan Gembala Sidang gereja setempat.

\section{PENGUMPULAN DATA PENELITIAN}

Untuk pengumpulan data penelitian, penulis menggunakan dua macam jenis pengumpulan data, yaitu: Pertama adalah wawancara. Dalam wawancara ini, penulis akan mengajukan pertanyaan-pertanyaan kepada subjek penelitian, baik secara perseorangan atau berkelompok untuk mendapatkan informasi tentang variabel penelitian. Kedua adalah kuisioner, isinya antara lain skala profil dan tes kepada subjek penelitian.

\section{ANALISA PENELITIAN}

Agar kajian tesis ini tetap berorientasi pada tujuan yang hendak dicapai, penulis akan menganalisis data yang telah terkumpul. Dalam menganalisa data, ada dua jenis statistik yang dipakai, yaitu statistik deskriptif dan statistik inferensial. Statistik deskriptif dipakai untuk menjelaskan dan meringkas data. Statistik inferensial dipakai untuk menarik inferensi-inferensi mengenai sebuah populasi dengan memakai data dari sampel populasi.

\section{TINJAUAN PUSTAKA}

Sebagai landasan teoritis bagi penulis terhadap topik yang akan dibahas, penulis perlu membuat tinjauan literatur berdasarkan pokok bahasan. Tinjauan literatur ini akan penulis kemukakan dalam tiga pokok bahasan yaitu: Latar Belakang Surat Satu Korintus, Kondisi Kota Korintus, dan Profil Rasul Paulus sebagai hamba Tuhan dalam Surat Satu Korintus.

\section{LATAR BELAKANG SURAT SATU KORINTUS}

Pada waktu perjalanan misi yang ketiga, Paulus singgah di Korintus menuju Efesus. Ia mendengar kabar buruk dari anggota-anggota rumah tangga Kloe tentang jemaat Korintus. Ada beberapa hal yang menyatakan kemunduran rohani jemaat Korintus, masingmasing dibahas oleh J. Wesley Brill dalam buku, "Tafsiran Surat Korintus Pertama", V.C. Pfitzner dalam buku, "Ulasan Atas 1 Korintus: Kesatuan dalam Kepelbagaian" , dan Merill C. Tenney dalam buku, "Survey 
Perjanjian Baru". Sedangkan Robert B. Hughes dalam buku, "First Corinthians, Everyman's Bible Commentary" menunjukkan kabar buruk yang diterima Paulus tentang keadaan jemaat Korintus. Bukti-bukti adanya keburukan jemaat Korintus dibahas John Drane dalam buku, "Memahami Perjanjian Baru", disebabkan perpecahan karena adanya kelompok Paulus, Kefas, Apolos, dan Kristus.

Ola Tulluan dalam buku, "Introduksi Perjanjian Baru", menulis kemunduran jemaat Korintus seperti perpecahan dalam jemaat (1 Kor. 1:10), dosa percabulan (1 Kor. 5:1) karena ada orang yang hidup dengan istri ayahnya (1 Kor. 5:1). Mencari keadilan pada orang-orang yang tidak beriman (1 Kor. 6:1). Masalah perkawinan (1 Kor. 7:1) dan karuniakarunia roh (1 Kor. 12-14). Dan selanjutnya masalah kebangkitan Kristus dan kebangkitan tubuh (1 Kor. 15).

Everett F. Harrison dalam buku, "Tafsiran Alkitab Wycliffe - 1 Korintus", menuliskan bahwa masalah di jemaat Korintus terbagi menjadi beberapa kelompok yaitu, Kelompok Paulus yang mengandalkan kebebasan iman di dalam Injil Yesus Kristus, Kelompok Apolos lebih menyenangi gaya dan retorika yang lebih halus dari orang Aleksandria yang berbakat itu. Kelompok Kefas tampaknya meragukan mandat Paulus, kelompok Kefas lebih memilih hubungan dengan Yerusalem melalui Petrus. Orangorang yang termasuk golongan Kristus menganggap rendah semua hubungan dengan golongan-golongan lain itu sehingga menjadi golongan tersendiri.

\section{KONDISI KOTA KORINTUS}

Secara umum kota Korintus menjadi

kota perniagaan karena terletak di persimpangan jalan antara wilayah Yunani dan Timur Tengah. Secara geografi, letak Korintus sebagai kota di pinggir dua lautan yang menghubungkan Korintus dengan kota-kota lainnya, ditulis oleh Russel P. Splitter dalam buku, "Pertama \& Kedua Korintus". Dan Charles Ludwig dalam buku, "Kota-kota pada zaman Perjanjian Baru" menulis letak kota Korintus kurang lebih lima puluh mil sebelah barat kota Atena dengan jalan raya yang megah menghubungkan kota Atena dengan kota Korintus.

William Barclay dalam buku, "Duta bagi Kristus, Latar Belakang Peta Perjalanan
Paulus" menyatakan bahwa kota Korintus sebagai kota perdagangan yang mendatangkan barang-barang berharga seperti minyak balsam Arab, lontar Mesir, kurma Fenisia, gading Libia, permadani Babel, bulu kambing Kilikia, bulu domba Lakaonia, dan juga budak-budak dari Frigia.

Memang sebagai kota perdagangan dan kota pelabuhan yang berkembang mengundang penduduk campuran dari Timur dan Barat sehingga menimbulkan kegiatan yang berkaitan dengan kejahatan dan imoralitas seksual, seperti yang ditulis oleh V.C. Pfitzner dalam buku, "Ulasan Atas 1 Korintus: Kesatuan dalam Kepelbagaian"

Dalam hal kerohanian, kota Korintus menjadi tempat yang baik untuk penyebarluasan ajaran-ajaran sesat yang dibawa orang Yahudi, orang Yunani, dan orang Timur. F.F. Bruce dalam buku, "Tafsiran Alkitab Masa Kini Jilid 3 - 1 Korintus" menyatakan orang Korintus memiliki latar belakang pendidikan sangat menyukai ajaran filsafat seperti Epikuros dan Stoa. Ajaran Epikuros ialah menyatakan kebaikan tertinggi untuk mencari kesenangan dan kepuasan manusia.

Ajaran filsafat Stoa menyatakan kebaikan tertinggi ialah mencukupkan kebutuhan diri sendiri (manusia). William Barclay, dalam buku, "Duta bagi Kristus, Latar Belakang Peta Perjalanan Paulus", menuliskan bahwa Epikuros menekankan tujuan akhir dari hidup ialah hanya kesenangan saja. Dan ajaran Stoa menekankan segala sesuatu di dunia ini sesungguhnya adalah Allah.

Sebagai tempat yang ramai dikunjungi pendatang tidak tertutup kemungkinan masuknya pengaruh budaya luar dan kesusilaan bebas yang dibawa para pendatang ke Korintus. Bruce Chiltor dalam buku, "Studi Perjanjian Baru bagi Pemula".

Ola Tulluan, dalam buku, "Introduksi Perjanjian Baru" menuliskan bahwa orang Korintus masih mengikuti ajaran sesat seperti penyembahan berhala, pergaulan bebas tanpa persekutuan dengan Allah.

Secara moral Korintus adalah kota yang hina karena terdapat kuil dewa Afroditus, yang dihuni oleh seribu orang imam wanita yang semuanya pelacur, demikian Merril C. Tenney dalam buku, "Survei Perjanjian Baru". 


\section{PROFIL RASUL PAULUS SEBAGAI HAMBA TUHAN DALAM SURAT SATU KORINTUS}

Sebagai seorang yang taat kepada tradisi Yahudi, maka Paulus telah belajar hukum Taurat dan Perjanjian Lama sejak usia enam tahun di rumah sembahyang orang Yahudi atau sinagoge.

Dalam kehidupannya sebagai ahli Taurat dan tradisi Perjanjian Lama, maka Tuhan Yesus Kristus memanggilnya sebagai hamba-Nya. Paulus menerima kasih karunia Allah untuk bertobat dari kehidupannya. J. Knox Chamblin dalam buku, "Paulus dan Diri, Ajaran Rasuli Bagi Keutuhan Pribadi". Tom Jacobs dalam buku, "Paulus, Hidup, Karya dan Teologinya", pertobatan Paulus dalam pengalaman di Damsyik adalah sungguhsungguh suatu wahyu baginya atau suatu penyataan Yesus Kristus yang mempersatukan Paulus dengan Allah dalam Kristus.

Susilaradeya dalam buku, "Jalan Menuju Kebenaran", menulis motivasi hamba Tuhan yang benar ialah pertama, kesetiaan, dinyatakan dari sikap hidup orang lain. Kedua, kejujuran, dinyatakan dalam perbuatan sehingga dapat meningkatkan persekutuan satu dengan yang lain. Ketiga, tanggung jawab, bersedia memikul beban yang terdapat pada sesama dan menyelesaikan dari Firman Tuhan sebagai sumber penyelesaian permasalahan.

Paulus diutus melayani orang Yahudi dan non-Yahudi baik di Yerusalem maupun yang berada di luar Yerusalem. Merril C. Tenney dalam buku, "Survei Perjanjian Baru", Paulus melakukan perjalanan misi pertama bersama Barnabas dan Markus berangkat ke Seleukia dan berlayar ke Siprus, Antiokhia, Listra, Derbe, dan Ikonium.

Ola Tulluan dalam buku, "Introduksi Perjanjian Baru", menuliskan bahwa perjalanan misi kedua Paulus bersama Silas dilakukan dengan menyeberangi laut Aegea menuju Eropa (Kis.16:9-10) dan mengunjungi Filipi, Tesalonika, dan Berea.

John Drane, dalam buku, "Memahami Perjanjian Baru", menuliskan bahwa Paulus melakukan perjalanan misi ketiga. Yang menjadi sasaran pelayanan Paulus adalah Asia Kecil di Efesus sebagai ibukota propinsi Asia.
Selama hampir tiga tahun kota Efesus, merupakan pusat pelayanan Paulus.

Donald Guthrie dalam buku, "Teologi Perjanjian Baru 2, Misi Kristus, Roh Kudus, Kehidupan Kristen", menuliskan bahwa pengajaran Paulus tentang hukum Taurat itu bersifat kudus, dan sebagai ukuran penghakiman Allah.

George Eldon Ladd dalam buku, "Teologi Perjanjian Baru Jilid 2, menulis pengajaran Paulus tentang hukum Taurat berdasarkan pengalaman Paulus sendiri, bahwa ia adalah orang Yahudi yang taat dan seorang Farisi yang tak bercacat dalam ketaatannya.

Donald Guthrie dalam buku, "Teologi Perjanjian Baru 1, Allah, Manusia, Kristus", menuliskan bahwa pengajaran Paulus tentang manusia diistilahkan sebagai nyawa atau psuke, roh atau pneuma, daging atau sarx, tubuh atau soma, hati atau kardia, dan akal budi atau nous.

Millard J. Erickson dalam buku, "Teologi Kristen Volume Dua", istilah manusia dalam 1 Korintus 2:14-3:4 di mana Paulus membagi manusia menjadi tiga bagian yaitu manusia dunia atau sarkisos, manusia yang tidak menerima apa yang berasal dari roh, secara harfiah berasal dari jiwa atau huikos, dan manusia rohani atau pneumatikos.

Donald Guthrie dalam buku, "Teologi Perjanjian Baru 2, Misi Kristus, Roh Kudus, Kehidupan Kristen", menulis bahwa istilah penebusan atau apolutrosis berkaitan dengan karya keselamatan Kristus di dalam dunia. Penyataan Paulus dalam 1 Korintus 1:30, hanya Kristus yang membenarkan dan menguduskan serta menebus manusia.

Menurut George Eldon Ladd dalam buku, "Teologi Perjanjian Baru Jilid 2", menjelaskan bahwa ajaran Paulus tentang karya keselamatan Kristus sebagai penebusan atau apolutrosis. Penebusan juga dinyatakan oleh kata kerja agorazo yang berarti membeli (1 Kor.6:19,20). Paul Enns, dalam buku, "The Moody Handbook of Theology, Buku Pegangan Theologi 1", mengemukakan bahwa ajaran Paulus tentang penebusan atau apolutrosis dipakai sebanyak sepuluh kali. Penebusan berarti membebaskan dengan cara pembayaran dengan suatu harga tertentu.

Donald Guthrie dalam buku, "Teologi Perjanjian Baru 3, Eklesiologi, Eskatologi, Etika, menjelaskan tentang ajaran Paulus yang berkenaan dengan etika manusia 
berkaitan dengan etika Yesus dalam kasih atau agape.

Menurut George Eldon Ladd, dalam buku, "Teologi Perjanjian Baru Jilid 2", sikap etika Kristen Paulus, bahwa Roh Allah yang bekerja dalam hati manusia adalah penuntun etika yang cukup.

Donald Guthrie dalam buku, "Teologi Perjanjian Baru 3, Eklesiologi, Eskatologi, Etika”, menegaskan bahwa ajaran Paulus tentang jemaat atau gereja menunjuk kepada gereja Korintus /di alamatkan kepada jemaat Allah di Korintus (1 Kor.1:2; 2 Kor.1:1).

Menurut George Eldon Ladd, dalam buku, "Teologi Perjanjian Baru Jilid 2", istilah gereja atau jemaat (Ekklesia) yaitu pertemuan orang-orang Kristen untuk berbakti (1 Kor.11:18; 14:19,28,35). Milliard J. Erickson, dalam buku, "Teologi Kristen Volume tiga", menegaskan bahwa pengertian gereja atau ekklesia dipakai Paulus yang ditunjukkan kepada jemaat Allah di Korintus (1 Kor.1:2). Gereja juga sebagai bait Allah dan kudus, sebagai tempat kediaman Allah (1 Kor.3:1617).

Paul Enns, dalam buku, "The Moody Handbook of Theology, Buku Pegangan Jilid 1", menegaskan bahwa gereja atau ekklesia berarti orang percaya yang Allah panggil keluar dari dunia menjadi suatu kelompok milik Allah (1 Kor.1:2,4:17,7:17).

Donald Guthrie dalam buku, "Teologi Perjanjian Baru 3, Eklesiologi, Eskatologi, Etika", ajaran Paulus tentang hari terakhir atau hari Tuhan menunjuk kepada peristiwa kedatangan Kristus kedua kali (1 Kor.1:8).

George Eldon Ladd, dalam buku, "Teologi Perjanjian Baru Jilid 2", ajaran Paulus tentang eskatologi menggunakan tiga istilah untuk menjelaskan kedatangan Tuhan Yesus kedua kali yaitu: Parousia, yang berarti kehadiran dan kedatangan (1 Kor.16:17), Apokalypsis yaitu suatu pengungkapan atau penyataan Kristus pada dunia ( 1 Kor.15:25) dan Epiphaneia yaitu penampakan menunjukkan kedatangan Kristus yang terlihat oleh dunia.

Paul Enns, dalam buku, "The Moody Handbook of Theology, Buku Pegangan Teologi Jilid 1", ajaran Paulus tentang kembalinya Kristus ke dunia merupakan peristiwa yang dinantikan orang percaya dengan penuh sukacita.

Menurut Millard J. Erickson, dalam buku, "Teologi Kristen Volume tiga", ajaran
Paulus tentang eskatologi berkaitan dengan penggenapan sejarah, di mana Kristus sendiri turun ke dunia diiringi kemuliaan-Nya.

Millard J. Erickson, dalam buku, "Teologi Kristen Volume Tiga", ajaran Paulus tentang keselamatan, sebagai bersatu dengan Kristus. Persatuan dengan Kristus menggambarkan Kristus dan orang percaya saling berada di dalam satu sama lain (1 Kor.1:4-5).

Menurut Paul Enns, dalam buku, "The Moody Handbook of Theology, Buku Pegangan Teologi Jilid 1", ajaran Paulus tentang keselamatan berpusat pada anugerah Allah.

\section{SIMPULAN}

Setelah menelusuri latar belakang masalah dalam penelitian ini dan mencermati profil rasul Paulus melalui literatur maka penulis memberikan kesimpulan sebagai berikut:

Hal mendasar yang perlu dipahami tentang pengajaran rasul Paulus tentang profil hamba-hamba Tuhan di gereja GPdI, bahwa gereja GPdI adalah sebuah gereja yang semakin berkembang baik dalam bentukbentuk pelayanannya maupun pertambahan jemaatnya dan juga pembangunan fisik yang semakin melebar.

Dengan perkembangan tersebut akan menjadikan pelayanan semakin menghadapi banyak tantangan. oleh karena itu, seorang hamba Tuhan di gereja GPdI adalah seorang pastor yang memiliki profil yang tanggung jawab untuk mengubah, membentuk, dan memperlengkapi jemaat. Dilihat dari teladan dan profil yang telah diberikan oleh rasul Paulus kepada jemaat di Korintus ketika dia melayani di sana.

Ia melayani sebagai seorang pemimpin jemaat, ia bukan panggilan, tetapi ia menyambut panggilan itu, karena ia telah menjalani pembentukan karakter dan juga diperlengkapi. Ia telah mengambil suatu komitmen untuk melaksanakan panggilan Tuhan dalam memberikan pengajarannya tentang profil hamba-hamba Tuhan di jemaat Korintus.

Hanya mereka yang meyakini panggilan, menghargai panggilan, memahami maksud dan tanggung jawab panggilan yang akan terus bertahan di dalam pelayanan sebagai pemimpin jemaat. Ia harus menyadari 
bahwa ia adalah seorang hamba yang dipertanggungjawab oleh tuannya untuk melayani umat-Nya dalam hal pengajaran.

Bentuk apapun pelayanan pengajaran profil hamba-hamba Tuhan haruslah berdasarkan Alkitab. Itu sebabnya kemampuan dan tanggung jawab teología haruslah menjadi hal yang utama, namun untuk mencermati fenomena abad ke-21 yang dikenal sebagai zaman teknologi dan sains, pelayanan pengajaran profil hamba-hamba Tuhan menuntut hamba-hamba Tuhan memiliki kemampuan untuk menunjukkan profil tetap relevan di tengah-tengah jemaat Gereja Pantekosta di Indonesia.

\section{KEPUSTAKAAN}

[1] Alkitab, Jakarta: Lembaga Alkitab Indonesia, 2003.

[2] Abineno, J.L. Ch., Penatua Jabatan dan Pekerjaannya, Jakarta: Gunung Mulia. 2003.

[3] Anderson, C. Robert. The Effective Pastor, Chicago: Moody Press. 1985.

[4] Banks, Robert. Paul's Idea of Community, Exeter: Patemoster Press, 1982.

[5] Barclay, William. Ambassador For Christ, Edinburgh: Saint Andrew Press, 1980.

[6] Barnett, Jake.Wealth \& Wisdom, A Biblical Perspective On Possession, Colorado: NAV Press Publishing, 1987.

[7] Barlett, David L. Pelayanan dalam Perjanjian Baru, Jakarta: BPK Gunung Mulia, 2000.

[8] Barna, George. Habits of Highly Effective Churches, Malang: Gandum Mas, 2003.

[9] Berkhof, Louis. Teologi Sistematika: Doktrin Kristus, Jakarta: LRII, 1996.

[10] Best, Ernest. Paul and His Converts, Edinburgh: T \& T, Clark Ltd., 1988.

[11] Bons, M., Storm. Apakah Pengembalaan itu? Jakarta: BPK Gunung Mulia, 2004.

[12] Bosch, David J. Transformasi Misi Kristen, Jakarta: BPK Gunung Mulia, 1982.

[13] Brand, Robert L Kuasa Allah Untuk Masa Kini, Malang: Gandum Mas, 1982.

[14] Bromiley, Geoffrey L. Theological Dictionary of The New Testament Volume VIII, edited by Gerhard Kittel, Grand Rapids, Michigan: WM.B.Eerdmans Publishing, 1979.

[15] Brown, Colin. Dictionary of New Testament Volume 3, Michigan: Zondervan Publishing House, 1985.

[16] Bruce, F. F. The New Testament History, New York: Dubleday Galilee, 1980.
[17] Bruce, F. F. Paul, Apostle of the Heart Set Free, Grand Rapids, 1990.

[18] Brill, J. Wesley. Tafsiran Surat Korintus Pertama, Bandung: Kalam Hidup, 1988.

[19] Calvin, J. The Epistles of Paul to the Romans and to the Thessalonians, Edinburg: St Andrew Press, 1961.

[20] __ The Second Epistle of Paul to the Corinthians and Epistle to Timothy,

Titus, and Philemon, Edinburgh: St. Andrews Press, 1961.

[21] Carson, D.A., Douglas J. Moo, Leon Morris An Introduction of The New

Testament, USA: Zondervan Publishing House, 1991.

[22] Chafer, Lewis Sperry. Systematic Theology Volume 6, Dallas: Dallas Seminary,

1948.

[23] Chamblin, Knox J. Paulus Dan Diri, Ajaran Rasuli Bagi Keutuhan Pribadi,

Surabaya: Momentum, 2006.

[24] Charles, Ludwig. Kota-kota Pada Zaman Perjanjian Baru, Bandung: Kalam

Hidup, 1975.

[25] Chilton, Bruce. Studi Perjanjian Baru Bagi Pemula, Jakarta: BPK Gunung

Mulia. 1994.

[26] Conner, Kevin J. The Church in the New Testament, Malang: Gandum Mas, 2003.

[27] Conybeare, W.J., Howson, J.S. Life and Epistles of St. Paul, Michigan: WMB Eerdmans, 2004.

[28] Covey, Stephen.7 Kebiasaan manusia Yang Sangat Efektif, Jakarta: Binarupa Aksara, 1994.

[29] Cowles, Robert. Gembala Sidang, Bandung: Kalam Hidup, 1977.

[30] Drane, John. Memahami Perjanjian Baru, Jakarta: BPK Gunung Mulia, 1996.

[31] Dunnet, Walter M. Pengantar Perjanjian Baru, Malang: Gandum Mas,

1980.

[32] Faot, Agustinus, et al. "Bertahan Sampai Kesudahan Akan Diselamatkan."

Journal KERUSSO 4.1 (2019): 15-25.

[33] Foster, Richard J. Uang, Seks dan Kekuasaan, Tantangan Untuk Kehidupan Yang

Berdisiplin, Bandung: Yayasan Kalam Hidup, 1985.

[34] Griffiths, Michael. Ambillah Aku Melayani Engkau, Jakarta: BPK Gunung

Mulia, 1975.

[35] Groenen, C. Pengantar Ke Dalam Perjanjian Baru, Yogyakarta: Kanisius, 1995. 
[36] Gromacki, Robert G. New Testament Survey, Michigan: Baker Book House, 1989.

[37] Guthrie, Donald. Teologi Perjanjian Baru Volume 1,2,3, Jakarta: BPK Gunung

Mulia, 1992.

[38] Haag, Herbert. Kamus Alkitab, Yogyakarta: Kanisius, 1992.

[39] Hall, Brian P. Panggilan Akan Pelayanan: Citra Pemimpin Jemaat, Jakarta: BPK Gunung Mulia, 1992.

[40] Harrison, Everett F. Tafsiran Alkitab Wycliffe - 1 Korintus, Malang: Gandum Mas, 2001.

[41] Hawthorne, Gerald F. (Ed.). Dictionary Of Paul And His Letters, A Compendium

Of Contemporary Biblical Scholarship, Leceister, England: Intervarsity Press, 1993.

[42] Henry, Carl P.H (Ed.). Baker's Dictionary Of Christian Ethics, America: Baker

Book House, 1973.

[43] Henry, Matthew. Matthew Henry's Commentary On The Whole Bible Complete

And Unabrigged, Chester: Hendrickson Publishers, 2002.

[44] Howard, David M. By The Power Of The Holy Spirit, Illinois, Intervarsity Press, 1975.

[45] Jacobs, SY, T. Paulus: Hidup, Karya, dan Teologinya, Jakarta: BPK Gunung

Mulia, 1983.

[46] Johnson, S. Lewis. I Corinthians, The Wycliffe Bible Commentary Vol 3, Chicago: Moody Bible Institute, 1962.

[47] Juanda, J. (2017). Melayani Kristus Dengan Karya Tulis. Journal Kerusso, 2(1), 45-54.

[48] Juanda, J., \& Andaline, Z. V. (2019). Menghadapi Ajaran Sesat. Journal Kerusso, 4(1), 1-5.

[49] Kent, Homer A., Expositor's Bible Commentary, Philipians, Michigan: Zondervan Corporation Grand Rapid, 1978.

[50] Kittel, Gerhard \& Gerhard Fiedrich (Ed.), Theological Dictionary Of The New

Testament, Abridged in one Volume, Michigan: William B. Eerdmans, 1985.

[51] Ladd, George Eldon. Teologi Perjanjian Baru, Jilid 2, Bandung: Yayasan Kalam

Hidup, 2002

[52] Lawrance, Bill. Effective Pastoring, Tennesse: Thomas Nelson, Inc., 1999.

[53] Longenecker, Richard N. The Ministry and Message of Paul, Michigan:

Zoncervan Publishing House, 1971.
[54] Lontoh, Frederich Oscar. "Pengaruh Gaya Kepemimpinan, Ketrampilan

Komunikasi Dan Kotbah Terhadap Komitmen Organisasional Jemaat Di GKI Dasa

Surabaya." Journal Kerusso 2.1 (2017): 1-17.

[55] Lumintang, Stevri I. Theologia \& Missiologia Reformed, Batu:

Departemen

Literatur PPII. 2003.

[56] Majalah Sahabat Awam No. 11, (Bandung: Yayasan Bina Awam, 1988), 14

[57] Majalah Sahabat Awam No. 12, (Bandung : Yayasan Bina Awam, 1988) 19

[58] Majalah Bahana NO.07/Th.V/Vol.46, 7 Januari, (Yogyakarta: Yayasan Andi,

1995), 28-29

[59] Majalah Sahabat Awam N0.27, (Bandung: Yayasan Bina Awam, 1997), 5

[60] Majalah Sahabat Gembala Bulan Mei, (Bandung: Yayasan Kalah Hidup, 2004),

32-33.

[61] Mimery, Nehemia. Pedoman Penggembalaan Sidang, Bandung: Penerbit

Nehemia Mimery, 1969.

[62] Mish, Frederick C. Merriam Webster's Collegiate Dictionary, Tenth Edition,

USA: Webster's Company, 1998.

[63] Mare, W. Harlod. I Corinthians: The Expositor's Bible Commentary vol 10,

Michigan: The Zondervan Corporation, 1976.

[64] Murphey, Cecil. The Enciclopedia Of Christian Marriage, America: Flemming

H. Revel Company, 1984.

[65] Pemahaman Alkitab Setiap Hari: Surat 1 \& 2 Korintus, Jakarta: BPK Gunung

Mulia, 2008.

[66] Prasetyo, Widi, et al. "Measuring the Quality of God's Servants According to Acts 6: 3 At the Surabaya City Tabernacle Pentecostal Church." Journal KERUGMA 2.1 (2019): 24-33.

[67] Riedel, K. Surat yang Pertama kepada orang Korintus, Jakarta: Badan Penerbit Kristen, 1955.

[68] Riggs, Ralph M. Gembala Sidang Yang Berhasil, Malang: Gandum Mas, 1978.

[69] Rumiyati, Rumiyati, et al. "Pengaruh Kepemimpinan Hamba Tuhan Dalam Pertumbuhan Kerohanian Jemaat Gereja GPdI 'Zion'Krebet, Tembalang, WlingiBlitar." Journal Kerusso 3.2 (2018): 919.

[70] Ryrie, Charles Caldwell. The Ryrie Study Bible: New American Standard 
Translation, Chicago: Moody Press, 1978.

[71] Stamps, Donald C. (Ed.). Alkitab Penuntun Hidup Berkelimpahan, Malang: Gandum Mas, 1994.

[72] Spittler, Russell P. Pertama \& Kedua Korintus, Malang: Gandum Mas, 1977.

[73] Sproul, R.C. Kebenaran-Kebenaran Dasar Iman Kristen,Malang: SAAT, 1997.

[74] Subagyo, Andreas W. Pengantar Riset Kuantitatif \& Kualitatif, Bandung: Kalam

Hidup, 2004.

[75] Sugiyono. Metode Penelitian Kuantitatif Kualitatif Dan R\&D, Bandung:

Alfabeta, 2006.

[76] Sukahar, H. Potret Pendeta, Malang: Gandum Mas, 1999.

[77] Sumanto, M.A. Metodologi Penelitian Sosial dan Pendidikan, Yogyakarta: Andi Offset 1990.

[78] Susilaradeya. Jalan Menuju Kebenaran, Jakarta: Yayasan Komunikasi Bina

Kasih/OMF, 1985.

[79] Swindoll, Charles R. Paul, Jakarta: Nafiri Gabriel, 2004.

[80] Tenney, Merrill C. Survei Perjanjian Baru, Malang: Gandum Mas, 2001.

[81] Tedball, Derek J. Teologi Pengembalaan, Malang: Gandum Mas, 1995

[82] Thiessen, Henry C. Teologi Sistematika, Malang: Gandum Mas, 1992.

[83] Todd, James H. Kristologi, Malang: Gandum Mas, 2003.

[84] Tong, Stephen. Baptism \& Karunia Roh Kudus, Surabaya: Momentum, 2005.

[85] Tulluan, Ola. Introduksi Perjanjian Baru, (Batu: YPPII), 2006.

[86] Wellem, F.D. Kamus Sejarah Gereja, Jakarta: BPK Gunung Mulia, 1994.

[87] Wenham, David. Paul Follower Of Jesus or Founder Of Christianity? Grand

Rapids, Michigan: Wm. Eerdmans Publishing Company, 1995.

[88] Wesley, Brill J. Tafsiran Surat Korintus Pertama, Bandung: Kalam Hidup, 1988. 